\title{
Draft Genome Resources of Two Strains ("ESVL" and "IVIA5901") of Xylella fastidiosa Associated with Almond Leaf Scorch Disease in Alicante, Spain
}

\author{
Annalisa Giampetruzzi, ${ }^{1}$ María Pilar Velasco-Amo, ${ }^{2}$ Ester Marco-Noales, ${ }^{3}$ Miguel Montes-Borrego, ${ }^{2}$ \\ Miguel Román-Écija, ${ }^{2}$ Inmaculada Navarro, ${ }^{3}$ Adela Monterde, ${ }^{3}$ Silvia Barbé, ${ }^{3}$ Rodrigo P. P. Almeida, ${ }^{4}$ \\ Pasquale Saldarelli, ${ }^{5}$ Maria Saponari, ${ }^{5}$ Vito Montilon, ${ }^{1}$ Vito Nicola Savino, ${ }^{1}$ Donato Boscia, ${ }^{5}$ and \\ Blanca B. Landa ${ }^{2, \dagger}$ \\ ${ }^{1}$ Dipartimento di Scienze del Suolo della Pianta e degli Alimenti, Università degli Studi di Bari Aldo Moro, \\ 70126 Bari, Italy \\ ${ }^{2}$ Institute for Sustainable Agriculture, Consejo Superior de Investigaciones Científicas (IAS-CSIC), 14004 \\ Córdoba, Spain \\ ${ }^{3}$ Centro de Protección Vegetal y Biotecnología, Instituto Valenciano de Investigaciones Agrarias (IVIA), \\ 46113 Moncada, Spain \\ ${ }^{4}$ Department of Environmental Science, Policy and Management, University of California, Berkeley 94720 \\ ${ }^{5}$ Istituto per la Protezione Sostenibile delle Piante, CNR, 70126 Bari, Italy
}

\begin{abstract}
An outbreak of Xylella fastidiosa subsp. multiplex sequence type ST6 was discovered in 2017 in mainland Spain affecting almond trees. Two cultured almond strains, "ESVL" and "IVIA5901," were subjected to high throughput sequencing and the draft genomes assembled. Phylogenetic analysis conclusively indicated they belong to the subspecies multiplex, and pairwise comparisons of the chromosomal genomes showed an average nucleotide identity higher than $99 \%$. Interestingly, the two strains differ for the presence of the plasmids pXF64-Hb_ESVL and pUCLA-ESVL detected only in the ESVL strain. The availability of these draft genomes contribute to extend the European genomic sequence dataset, a first step toward setting new research to elucidate the pathway of introduction and spread of the numerous strains of this subspecies so far detected in Europe.
\end{abstract}

\section{Genome Announcement}

In 2017, Xylella fastidiosa was detected for the first time in mainland Spain, on almond trees in the Guadalest Valley, Alicante province (Valencian Community). In this province, in spring 2018 infections had been detected in more than 170 almond orchards located in 27 municipalities (EFSA PLH Panel 2018). The number of affected orchards is currently higher as the official surveillance in the area is progressing. Infected trees showed noticeable symptoms of almond leaf scorch disease (ALSD), with typical yellow and brown lesions on leaf tips and margins, but also extensive branch and twig dieback. Infections have also been discovered on Rosmarinus officinalis and five additional ornamental species and scrubland Mediterranean vegetation.

Multilocus sequence typing analyses performed directly on DNA extracts from infected almonds identified isolates genetically related to subsp. multiplex and sequence type ST6 (EFSA PLH Panel 2018). Isolates of the subsp. multiplex, native to temperate North America, are generally associated to leaf scorch diseases in various hosts (almond, plum, blueberry, pecan, and shade trees). The current status on the presence and occurrence of strains of

\footnotetext{
${ }^{\dagger}$ Corresponding author: B. B. Landa; E-mail: blanca.landa@csic.es
}

*The e-Xtra logo stands for "electronic extra" and indicates that one supplementary table is published online. Accepted for publication 18 October 2018
Funding

This work was funded by European Union's Horizon 2020 Framework Research Programme Projects XF-ACTORS (Xylella fastidiosa Active Containment Through a MultidisciplinaryOriented Research Strategy grant 727987) and MSCA-RISE-2016 CUREXF (Capacity Building and Raising Awareness in Europe and in Third Countries to Cope with Xylella fastidiosa); COST Action CA16107 EuroXanth, supported by European Cooperation in Science and Technology; and Project Desarrollo de estrategias de erradicación, contención y control de en España: Diagnóstico, estructura genética y gama de huéspedes project E-RTA2017-00004C06-02 from Programa Estatal de I+D+I Orientada a los Retos de la Sociedad of the Spanish Government. This work used the Vincent J. Coates Genomics Sequencing Laboratory at University of California, Berkeley, supported by $\mathrm{NIH}$ S10 OD018174 Instrumentation Grant. 
different $X$. fastidiosa subspecies in the three European countries (Italy, France, and Spain) indicates that strains of the subsp. multiplex are the most common, with the highest number of STs identified, including a new undescribed ST (ST81) (EFSA PLH Panel 2018). Previous reports in Europe indicated that strains of subsp. multiplex (ST6-ST7) are widespread in Corsica (Denancé et al. 2017) and in two Balearic Islands (ST7-ST81) (Olmo et al. 2017) in the outbreaks detected in southern France (PACA region, ST6-ST7) and more recently in those detected in mainland Spain, both in the province of Alicante (ST6) and Madrid (ST6).

In this report, we describe the draft genome sequences of $X$. fastidiosa strains "ESVL" and "IVIA5901", selected among the ST6-cultured isolates recovered from ALSD-affected almond trees from two orchards located in Bolulla and Benimantell municipalities (Alicante province), distant from each other by approximately $8 \mathrm{~km}$. Genomic DNA of strains ESVL and IVIA5901 were extracted from pure cultures grown in PD2 agar medium using a commercial DNA purification kit. The whole genome sequencing (WGS) libraries were paired-end sequenced with a HiSeq4000 Illumina platform. WGS library for ESVL was run in three technical replicates on three different lanes, and WGS library of IVIA5901 was run in one replicate.

Illumina sequencing yielded a total of $1,369,695,2 \times 150 \mathrm{bp}$ high quality paired reads for ESVL and a total of 3,956,773, $2 \times 150 \mathrm{bp}$ for IVIA5901. De novo genome assembly was done using SPAdes v3.9.0 (Antipov et al. 2016; Bankevich et al. 2012). Extremities of circular contigs annotated as plasmid sequence were trimmed and closed by PCR amplification with custom primers. The final assemblies of the bacterial chromosomes resulted in 131 contigs (>200 bp) for ESVL and in 141 contigs (>200 bp) for IVIA5901, with an equal GC content of $51.8 \%$ (Table 1). The nucleotide coverage of the chromosomal genome was $110 \times$ for ESVL and $309 \times$ for IVIA5901 (Table 1). The average nucleotide identity (ANI) between ESVL and IVIA5901 chromosomes calculated by ANI calculator tool (Rodriguez-R and Konstantinidis 2016) was $99.99 \%$.

In addition, for the strain ESVL, two plasmids were also assembled: pXF64-Hb_ESVL of $59,678 \mathrm{bp}$, with a GC content of $52.6 \%$, and pUCLA-ESVL of $1,289 \mathrm{bp}$, with a GC content of $54.7 \%$. Average nucleotide coverage was $27,741 \times$ for pUCLA-ESVL and $241 \times$ for pXF64$\mathrm{Hb}$ ESSL. To confirm, the presence/absence of both plasmids primers were designed (Supplementary Table S1) and used in PCR tests carried out on the corresponding cultured strains, and on several infected samples collected in the almond orchards. PCR results, sequencing, and BLAST analysis of amplified products confirmed the WGS data and disclosed the occurrence in the fields of ST6-infected plants either positive or negative for the presence of the two plasmids.

Functional annotation by submission to the NCBI Prokaryotic Genome Automatic Annotation Pipeline (PGAAP) resulted in the identification of 6 rRNA genes (two operons), 51 tRNA loci, 2,464 genes, 2,236 protein-encoding genes, 4 noncoding RNAs in the chromosome of IVIA5901 strain and 6 rRNA genes (two operons), 50 tRNA loci, 2,515 genes, 2,275 proteinencoding genes, 4 noncoding RNAs in the chromosome of ESVL strain; 61 protein-encoding genes in the pXF64-Hb_ESVL plasmid.

The plasmid pXF64-Hb_ESVL showed a high sequence similarity with the conjugative plasmid pXF64-HB (NZ_CP009886.1) reported in $X$. fastidiosa strain Hib4 (ST70), which belongs to the subsp. pauca. The plasmid pUCLA-ESVL showed highest sequence similarity with the rolling-circle plasmids PUCLAb and pUCLAc of the grape-infecting $X$. fastidiosa strain UCLA (Guilhabert et al. 2006).

A major difference found between the ST6 strains from Alicante is the absence of the two entire plasmids in strain IVIA5901.

In a previous work, the first genomic sequences of European strains of the subsp. multiplex harboring ST6 and ST7 genotypes, associated with outbreaks in Corsica and mainland France, were determined (Denancé et al. 2017). The genome sequences of the ST6 strains ESVL and

Table 1. Summary statistics of the genome assemblies of Xylella fastidiosa strains IVIA5901 and ESVL ${ }^{\mathrm{a}}$

\begin{tabular}{|c|c|c|c|c|c|c|c|c|c|c|c|}
\hline Strain & $\begin{array}{l}\text { Number of } \\
\text { supercontigs } \\
\text { ( } \geq 50,000 \mathrm{bp})\end{array}$ & $\begin{array}{c}\text { Number } \\
\text { of } \\
\text { contigs }\end{array}$ & $\begin{array}{l}\text { Number of } \\
\text { contigs plasmid } \\
\text { related }\end{array}$ & $\begin{array}{l}\text { Total } \\
\text { length } \\
\text { (bp) }\end{array}$ & $\begin{array}{l}\text { Genome } \\
\text { coverage }\end{array}$ & $\begin{array}{l}\text { N50 } \\
\text { (bp) }\end{array}$ & $\begin{array}{l}\text { N75 } \\
\text { (bp) }\end{array}$ & $\begin{array}{l}\text { Max } \\
\text { (bp) }\end{array}$ & $\begin{array}{l}\text { Min } \\
\text { (bp) }\end{array}$ & $\begin{array}{c}\text { GC } \\
\text { content (\%) }\end{array}$ & $\begin{array}{l}\text { Predicted } \\
\text { genes }\end{array}$ \\
\hline $\begin{array}{l}\text { ESVL } \\
\text { IVIA5901 }\end{array}$ & $\begin{array}{l}18 \\
16\end{array}$ & $\begin{array}{l}133 \\
141\end{array}$ & 2 & $\begin{array}{l}2,554,495 \\
2,493,558\end{array}$ & $\begin{array}{l}110 x \\
309 x\end{array}$ & $\begin{array}{l}103,116 \\
116,584\end{array}$ & $\begin{array}{l}67,809 \\
67,790\end{array}$ & $\begin{array}{l}335,582 \\
335,598\end{array}$ & $\begin{array}{l}207 \\
218\end{array}$ & $\begin{array}{l}51.8 \\
51.8\end{array}$ & $\begin{array}{l}2,515 \\
2,464\end{array}$ \\
\hline
\end{tabular}

a $\mathrm{N} 50=$ median length of more than $50 \%$ of the supercontigs in the entire assembly; N75 = median length of more than $75 \%$ of the supercontigs in the entire assembly; Max and Min = maximum and minimum lengths, respectively, of supercontigs found in the entire assembly; GC content = percentage of guanine-cytosine bases in the entire assembly; and Predicted genes = number of genes predicted by PGAAP (NCBI). 
IVIA5901 from mainland Spain further contribute to extend the genomic data available on the European strains of $X$. fastidiosa subsp. multiplex. The utility of such data for phylogenetic inference is critically to advance the investigations on the pathway of introduction(s), spread, genetic relationship among the European outbreaks, genomic population evolution, and determine divergence times from previously characterized strains in America and Europe.

Accession numbers. The genome sequences of $X$. fastidiosa strains ESVL and IVIA5901 have been deposited in GenBank under accession numbers QPQV01000000 and QPQW01000000, respectively. X. fastidiosa strains ESVL and IVIA5901 are being deposited at the Spanish Type Culture Collection (CECT).

\section{Acknowledgments}

We thank S. McDevitt (UCB Facility Director) for technical assistance. The equipment used for the bioinformatic analysis was from the "Rete di Laboratori Pubblici SELGE-Regione Puglia (cod. 14)" and from the datacenter ReCaS of the University of Bari Aldo Moro. We are grateful for the support of the Spanish Ministry of Agriculture, Fishery and Food to the National Reference Laboratory for Phytopathogenic Bacteria (IVIA) and the Institute for Sustainable Agriculture (CSIC).

\section{Literature Cited}

Antipov, D., Korobeynikov, A., McLean, J. S., and Pevzner, P. A. 2016. hybridSPAdes: An algorithm for hybrid assembly of short and long reads. Bioinformatics 32: 1009-1015.

Bankevich, A., Nurk, S., Antipov, D., Gurevich, A.A., Dvorkin, M., Kulikov, A. S., et al. 2012. SPAdes A new genome assembly algorithm and its applications to single-cell sequencing. J. Comput. Biol. 19:455-477.

Denancé, N., Legendre, B., Briand, M., Olivier, V., Boisseson, C., Poliakoff, F., and Jacques, M.-A. 2017. Several subspecies and sequence types are associated with the emergence of Xylella fastidiosa in natural settings in France. Plant Pathol. 66: 1054-1064.

EFSA PLH Panel (EFSA Panel on Plant Health), Jeger, M., Caffier, D., Candresse, T., Chatzivassiliou, E., Dehnen-Schmutz, K., Gilioli, G., Gregoire, J. C., Jaques Miret, J. A., MacLeod, A., Navajas Navarro, M., Niere, B., Parnell, S., Potting, R., Rafoss,
T., Rossi, V., Urek, G., Van Bruggen, A., Van der Werf, W., West, J., Winter, S., Almeida, R., Bosco, D., Jacques, M. A., Landa, B., Purcell, A., Saponari, M., Czwienczek, E., Delbianco, A., Stancanelli, G., and Bragard, C. 2018. Scientific opinion on the updated pest categorisation of Xylella fastidiosa. EFSA J. 16:5357.

Guilhabert, M. R., Stewart, V. J., and Kirkpatrick, B. C. 2006. Characterization of putative rolling-circle plasmids from the Gram-negative bacterium Xylella fastidiosa and their use as shuttle vectors. Plasmid 55:70-80.

Olmo, D., Nieto, A., Adrover, F., Urbano, A., Beidas, O., Juan, A., Marco-Noales, E., López, M. M., Navarro, I., Monterde, A., Montes-Borrego, M., Navas-Cortes, J. A., and Landa, B. B. 2017. First detection of Xylella fastidiosa infecting cherry (Prunus avium) and Polygala myrtifolia plants, in Mallorca Island, Spain. Plant Dis. 101:1820.

Rodriguez-R, L. M., and Konstantinidis, K. T. 2016. The enveomics collection: A toolbox for specialized analyses of microbial genomes and metagenomes. PeerJ Preprints 4:e1900v1. 